\title{
The role of the Old Testament in a violent world
}

\author{
Author: \\ Esias E. Meyer ${ }^{1}$ \\ Affiliation: \\ ${ }^{1}$ Department of Old \\ Testament Studies, \\ University of Pretoria, \\ South Africa \\ Correspondence to: \\ Esias Meyer \\ Email: \\ sias.meyer@up.ac.za \\ Postal address: \\ Private bag X20, Hatfield, \\ Pretoria 0028, South Africa \\ Dates: \\ Received: 04 Feb. 2011 \\ Accepted: 03 June 2011 \\ Published: 11 Nov. 2011 \\ How to cite this article: \\ Meyer, E.E., 2011, 'The role \\ of the Old Testament in a \\ violent world', Verbum et \\ Ecclesia 32(2), Art. \#502, \\ 8 pages. doi:10.4102/ \\ ve.v32i2.502 \\ Note: \\ This article was initially read \\ as a paper at a conference \\ held at the Centre for Public \\ Theology (University of \\ Pretoria) on 'Violence in the \\ democratic South Africa: A \\ challenge to theology and \\ the churches' on 11 August \\ 2010.
}

This article explores the responsibility of Bible critics with regard to the role that the Bible should play in our violent society. The crucial question that needs to be addressed is whether the Bible, and especially the Old Testament, is part of the problem or part of the solution. The Old Testament is clearly a violent book. How do we deal with this? Does the Old Testament really have a positive contribution to make in a society riddled with violence? Some Bible critics tend to shy away from these questions, but there are exceptions. For some, violence is so endemic to the Bible that there is little to save. For others, the Bible has a very constructive role to play in a society plagued by violence.

\section{Introduction}

The Bible is a collection of violent books. In the Old Testament God asks of Abraham to sacrifice his only son and Abraham sets out to do this, as if such a command is what one would expect of the deity. Later God kills the first born of the Egyptians, and later still Pharaoh and his army. These events produce that grand liberation narrative called the Exodus, but the Exodus has a dark side - the conquest and the Canaanites who are killed either directly or indirectly by this same God who delivered the Israelites from Egypt. In the New Testament things are slightly better, but this same God now sacrifices his own son, who will eventually return after much more violence has been committed (as the book of Revelation tells us); blood sacrifices, the ban, exile, conquest, blood revenge ... need I continue? The Bible is full of spilled blood. Still, one often hears the following argument: is it not surprising that a country such as South Africa, which is $80 \%$ Christian, is so violent? Critics of Christianity would answer: no, it is not surprising! What do you expect of people who read such a violent book and who believe in such a violent God?

This is a rather dramatic introduction, but there is a substantial amount of truth to it. Ever since the days of Marcion this question of the God of the Old Testament and the violent images used to portray him has been present in Christianity. These issues are thus not new, but in contemporary violent South Africa we still need to engage with them. In this article I will attempt to describe some of the ways in which biblical critics today take up this issue. I will first look at the contribution of some scholars who have argued that monotheism as portrayed in the Bible is in itself inherently violent. I will mostly focus on the work of Regina Schwartz, but I will also refer to the famous Egyptologist Jan Assmann. The arguments of both scholars could be used to say, with regard to the issue of violence in our society, that the Bible is more villain than hero, or in other words, the Bible is more part of the problem than part of the solution.

I will then engage with the work of Gerlinde Baumann, who has recently attempted to understand the violent images of God in the Old Testament. Baumann would still hope to use the Bible as part of the solution.

The biblical texts that will be discussed are mostly from the conquest narrative in the first half of Joshua. ${ }^{1}$ As we will see, it was an aspect of this narrative which triggered the writing of Schwartz's book, whilst Baumann has a whole chapter on the conquest narrative. ${ }^{2}$

The question that is addressed in this article is what role the biblical critic could play in this debate. We live in a violent world, we read a violent Book, and how are we to read responsibly? Should we follow those who simply regard the Old Testament as part of our problem of violence, or is it possible to read the Old Testament in a way which might reduce violence in our society?

It should also be said that this problem is related to the fact that we read ancient texts in a world in which violence is frowned upon. It should become clear in the rest of the article that the 1.For a good overview of the theological problems in interpreting the book of Joshua, see Noort (1998:15-24).

2.Brueggemann (2010) also wrote a little book about Joshua 11. Unfortunately the scope of his study does not extend much broader than that and Joshua 11 becomes a convenient vehicle for what he sets out to say. See also the review by Snyman (2010). 
ancient authors did not share our disgust of violence. Yet, as believers, we have this collection of books which bear witness to the different experience of other believers many centuries ago of the same God we claim to worship. We are embarrassed by the images the ancient authors chose to tell their own stories and the stories of their (our) God.

\section{Monotheism, violence and the Bible as part of the problem}

In 1997 two scholars published books which addressed the issue of monotheism and violence: Regina Schwartz, ${ }^{3}$ who was a professor of English and religion, published The curse of Cain: The violent legacy of monotheism, and the German Egyptologist Jan Assmann published Moses the Egyptian: The Memory of Egypt in Western Monotheism. ${ }^{4}$ Later, in 2010, Assmann published The price of monotheism. ${ }^{5}$ I will focus mostly on the work of Regina Schwartz but both could be regarded as scholars who would argue that the Bible is part of the problem of violence and not part of the solution.

Schwartz (1997:9) starts her book by recalling what she once experienced when teaching a first-year class on the importance of the Exodus narrative in theology and especially liberation theology. She was describing what role this narrative played in Latin America, South Africa and the civil rights movement in the US and then in the midst of what she calls this 'celebration', a student raised his hand and asked a simple question: 'What about the Canaanites?' She describes her reaction to this question as follows:

Suddenly all the uncomfortable feelings I had been repressing about the Bible for years flooded me. Yes, what about the Canaanites? and the Amorites, Moabites, Hittites?

(Schwartz 1997:9)

This experience with the first-year student thus triggered something which led to her book. In the first chapter of her book Schwartz (1997:3) engages with the story of Cain and Able, and asks why God had rejected Cain's sacrifice and preferred that of Able? What kind of a God is this? She answers this question by stating:

This God who excludes some and prefers others, who casts some out, is a monotheistic God - monotheistic not only because he demands allegiance to himself alone but because he confers his favour on one alone.

(Schwartz 1997:3)

In the rest of her book she argues that violence and the construction of identity go hand in hand and that in the Bible the issue of maintaining identity is intertwined with this monotheistic God. As she puts it:

This book is about violence. It locate that imagining identity as an act of distinguishing and separating from others, of boundary

3.See also Van Henten (2008:1590-1593) for a discussion of the work of Schwartz.

4.The original title German title of this book was Moses der Ägypter: Entzifferung einer Gedächtnisspur, which strangely enough, was published only in 2008. See Assmann 2010:122 n.4.

5.The original German title of this book was Die Mosaische Unterscheidung oder der Preis der Monotheismus, published in 2003. making and line drawing, is the most frequent and fundamental act of violence we commit.

(Schwartz 1997:5)

In the rest of the book she describes the tools used by the Old Testament to construct identity; these are covenant (Schwartz 1997:15-38), possession of land (39-76), kinship (77-119) and the construction of collective identity (120142). The construction of identity is driven by a principle of scarcity which, according to her, is prevalent in the Bible; this is the motivation behind certain groups being chosen ('us') and others ('them') not, as clearly everybody cannot have everything.

In her chapter on land Schwartz (1997:39-76) also deals with the conquest narrative in the book of Joshua, which she closely connects to the Exodus narrative. At one point Schwartz (1997:56) argues that one could read the Exodus rather cynically as a pretext for the conquest. Israel is first portrayed as a victim of the Egyptians, before they become the aggressor.

Later Schwartz (1997:60-61) describes how Bible scholars have engaged with these narratives. German scholars have questioned the historicity of these texts and have generally favoured a view that understands a far more gradual conquest of the land (as we will see later with Baumann). Marxists usually produced theories of peasant revolts. ${ }^{6}$ The end result of these kinds of readings is that all of them turn out to reflect an understanding of events that is 'less violent, less oppressive, and less morally repugnant than the version in the biblical narrative' (Schwartz 1997:61).

Schwartz (1997:61-62) argues that, unfortunately, these less violent interpretations do not change the cultural effect of these stories. People read the biblical stories as they are, the historical context is forgotten, and the stories linger. For Schwartz (1997:62), making these stories less offensive is not a responsible thing to do.

The last chapter of her book is about memory and the role it plays in constructing identity (Schwartz 1997:143-176). Right at the end of her book she concludes with a call to open up the biblical canon:

... and by that I do not mean some partial commentary of sanctified unalterable authoritative texts, but a genuine rewriting of traditions: new creation stories, new exoduses, new losses, and new recoveries of what is lost.

(Schwartz 1997:175-176)

For Schwartz the Bible is thus too inherently violent to be of much use today and it needs to be re-written and re-told as what Schwartz (1997:176) calls an 'alternative Bible that subverts the dominant vision of violence and scarcity'.

Jan Assmann's (1997) criticism of monotheism has taken a totally different route. He is more interested in the memory of Moses and the so-called Mosaic distinction between true

6.The book by Brueggemann (2010) could fit into this description. In Brueggemann's representation YHWH is clearly the liberating God who wants to destroy the oppressive power of the city kings. 
and false religion. He traces this distinction back to Pharaoh Akhenaten and his monotheistic reforms. The Mosaic distinction has, according to Assmann, led to bloodshed. In a book published in 2000, Assmann says about monotheism:

Wenn man die monotheistische Idee retten will, dann muss man sie ihrer inhärenten Gewalttätigkeit entkleiden. [If you want to save the idea of monotheism, its inherent violence has to be removed.]

(Assmann 2000:264)

It is not clear how Assmann proposes to do this. How will the monotheistic idea be 'removed' to reveal its inherent violence? In that sense Assmann's proposal could be regarded as not that far from Schwartz's. In response to the claims of both Schwartz and Assmann that monotheism is inherently violent, Collins (2004a) has recently responded:

Such claims are, no doubt, too simple. Violence and the sacred went hand in hand long before the rise of Akhenaten or Moses, and polytheism can be used to legitimate violence just as easily as monotheism.

(Collins 2004a:2)

Does the problem then lie with monotheism as such or with religion in general, especially religion serving the national agendas of certain nations? To this kind of criticism Assmann responds that he never argued that monotheism (or counterreligion) ${ }^{7}$ is more violent than polytheism (or primary religion):

Naturally, I do not believe that the world of the primary religions was free from hatred and violence. On the contrary, it was filled with violence and aggression in the most diverse forms, and many of these forms were domesticated, civilized, or even eliminated altogether by the monotheistic religions as they rose to power, since such violence was perceived to be incompatible with the truth they proclaimed. Yet neither can it be denied that these religions simultaneously brought a new form of hatred into the world: hatred for pagans, heretics, idolaters and their temples, rites, and gods.

(Assmann 2010:16)

For Assmann the question is not really whether monotheism is less or more violent than polytheism. He even acknowledges that certain kinds of violence were eliminated by monotheism and in that sense it was an improvement. Yet it brought with it a new kind of violence and a new kind of hatred, which was a step backwards.

Assmann (2010:16) also responds to criticism of his view of monotheism, which is said to claim that it is actually universal. Assmann asserts that this is a Christian definition of monotheism and not true of Judaism:

Judaism $^{8}$ is a culture of difference. For Judaism, it is utterly self-evident that monotheism draws a border and that the Jews

7. See Assmann (2010:8-14), where he distinguishes between primary and secondary or counter-religions. Examples of the latter would include most of the monotheistic religions we have in the world today along with Buddhism. These religions all make a 'truth' claim and portray themselves as the true religion, whilst their religious a 'truth' claim and portray themselves as the true religion, whilst their religious also called 'the Mosaic distinction', or in German, 'die Mosaische Unterscheidung'.

8.For an Old Testament scholar it is astounding that Assmann could move from certain texts in the Old Testament to precepts in Judaism, as if these are exactly the same. His views of Judaism are especially true of Second Temple texts in the Hebrew Bible, of which the Priestly text would probably be the best example with its obsessive of which the Priestly text would probably be the best example with
drawing and maintaining of boundaries between Jews and gentiles. are responsible for policing the border. Assimilation is not less abhorrent to Judaism than discrimination is to Christianity.

(Assmann 2010:17)

Judaism is thus about being different, but this does not mean that Judaism is more violent than Christianity or Islam. On the contrary:

Christianity and Islam, by contrast, do not recognize this border, and they have therefore lashed out in violence again and again throughout history.

(Assmann 2010:18)

Assmann (2010:17-18) also argues that violence in Judaism (as portrayed in the Hebrew Bible) is usually an 'internal affair', since the Israelites are meant to wipe out 'the Egyptians or Canaanites who dwell "among us", in our midst and in our hearts; they are directed inwards, not outwards'. This is not a very convincing argument, especially not in the light of the conquest narrative. The problem of the Canaanites does not disappear if the text says that they lived 'amongst Israel' (Assmann 2010:17-18). They did not suddenly become an 'internal problem' (Assmann 2010:17-18). They became an 'internal problem' (Assmann 2010:17-18) when, according to the Exodus narrative, Israel came from the outside and made Canaan their 'inside' (Assmann 2010:17-18). One cannot help but think of Schwartz's argument that the Exodus narrative was the perfect pretext for the conquest.

What Assmann and Schwartz have in common is, firstly, the fact that both would like to remove the violence from monotheism. How Assmann wants to do this is not clear, but Schwartz wants to rewrite the Bible. Both of them argue that the violence goes back to a theoretical construct. For Schwartz it is the God of the Bible who includes some and excludes others. For Assmann it is the distinction between true and false. Although these two principles are different, they have the same end result of excluding those whom God has not selected and those who serve a false religion.

Another response to Assmann came from Rainer Albertz (2009:373-387), who has argued that Israel was not always wholly monotheistic. ${ }^{9}$ After describing the development in Israelite religion from polytheism via monolatry to monotheism proper in the post-exilic period, Albertz (2009:386) concludes that there is no evidence that Israel or Judah became more aggressive than their polytheistic neighbours, since they introduced a more or less monolatric worship'. Thus Albertz would say that it cannot be argued that monotheism is intrinsically more violent than polytheism - at least not on the grounds of what we think we know of the history of the religion of ancient Israel. He then adds two further comments, of which the second one is particularly relevant to this debate.

Albertz (2009:386) argues from his historical overview that 'the violent means of the struggle for monolatry are restricted to those periods, when it was combined with social and political interest'. In this regard he refers to the violent end

9.This is acknowledged by Schwartz (1997:17) that, strictly speaking, there is no such thing as monotheism in the Old Testament, but that it should rather be called monolatry. 
of the Omride dynasty of the Northern Kingdom, which is described as being about the Omride dynasty's worship of other gods, whilst Albertz thinks it had more to do with the social and political realities of those days. The Omride dynasty was simply so resented because of the injustices it perpetrated that it had to be removed and the violence which accompanied their removal was a result of the bitter resentment.

Albertz (2009:386) also argues that Israel only discovered monotheism proper during the exile in a position of 'absolute powerlessness'. Israel's monotheistic belief was not in support of some ideology of world domination, but was actually the result of being dominated and being powerless. Albertz (2009:386-387) then adds that when the power of the omnipotent God was finally separated from the political power of his people, only then was the 'theological legitimacy of the monotheistic confession ... preserved'. Albertz (2009:387) concludes that our biblical tradition could be abused and that it is our responsibility to see that this does not happen.

One could thus describe both Schwartz and Assmann as scholars who regard the Bible and the kind of monotheism portrayed in it as a possible source of violence in our society. For both of them the Bible is part of the problem of violence and not the solution. I think that Schwartz would not be much interested in the criticism by Albertz, as she would probably regard it as another historical-critical attempt to make the violence in the Old Testament less offensive. It also seems that Schwartz is more interested in the Wirkungsgeschichte [reception history] of these texts and not necessarily in what they meant at the time. We will now turn to a scholar who attempts to use the Bible in a more positive fashion.

\section{Understanding or contextualising divine images of violence}

In her book entitled Gottesbilder der Gewalt im Alten Testament verstehen [Understanding Divine Images of Violence in the Old Testament] (2006) Gerlinda Baumann ${ }^{10}$ attempts to understand violent images God in the Old Testament. Before she presents her own approach to this problem, she offers a thorough overview of the approaches that biblical scholars have previously adapted to the violent texts in the Old Testament. She identifies at least twelve different strategies used by Bible critics to engage with violent divine images. There is no space to name them all, but the following are the most important.

The strategies vary from those which attempt to ignore violent texts to strategies which take these violent sides of divine images seriously, although they do this in different ways. For instance, some scholars would ignore the violent images of God by simply not mentioning or engaging with them (Baumann 2006:73). According to Baumann (2006:73),

10.Although Baumann (2006:37) explicitly chooses to focus on German-speaking literature, it still is unfortunate that she never engages with the work of Schwartz in her book. this has to do with society's negative value judgement of violence after the Second World War. Another similar strategy would be adopted by scholars who mention the violent divine images, but then argue that these do not belong to the 'Zentrum' [core] understanding of God (Baumann 2006:74). For them God can thus only be good, or loving, or faithful, but not violent, or bad at the same time. One could call these kinds of strategies a kind of ostrich politics, because they refuse to take these divine images seriously.

Another strategy would be to say that the violent divine images of the Old Testament are eventually replaced by images of God's love in the New Testament (Baumann 2006:74-75). Unfortunately this is based on a rather selective reading of New Testament texts, which ignore the violent images in these texts. ${ }^{11} \mathrm{~A}$ similar position to this would be what Baumann (2006:75) describes as a 'Strategie der Evolution' [strategy of evolution] in which one attempts to describe a development in the biblical presentation of God as a violent being. Usually this development is described as 'holy war' (Baumann 2006:75), which later became 'suffering servant' (Baumann 2006:75), and eventually leads to the death of Jesus on the cross. In the same vein many scholars have used the work of Girard, ${ }^{12}$ who has argued that sacrifices are necessary in society to control the violence which is endemic to society. The sacrifice of Jesus then becomes the final sacrifice which constrains violence in our society.

Other strategies entail those adopted by commentators who engage with these images, but understand them as an honest reflection of the world in which the text of the Old Testament originated (Baumann 2006:75-76). It was a world in which violence was very much part of everyday life. These texts function in a kind of therapeutic way. Similar, but more critical, is the strategy of calling to memory, which understands these violent texts as remembering concrete acts of violence committed against victims. This kind of reading often leads to an uncovering of hidden histories of violence. Baumann later uses some of these insights in her own engagement with different texts.

Yet another strategy is what Baumann (2006:76-77) calls adopting a historical perspective. The response of Albertz to Assmann might be an example of this, where Albertz argues that Israel was not always completely monotheistic and evokes the times when they were not necessarily more violent than during their polytheistic phases. Other strategies would, for instance, be to argue that the texts in Joshua, which tell us of how the Israelites conquered the Canaanites, are fictive, meaning that the events never really happened in that way. This does not really solve the whole problem, as the question is still why God was portrayed so violently and what the Wirkingsgeschichte [reception history] of these texts might be - thus the kind of questions which Schwarz asked. We will eventually return to these texts and these issues.

11.See, for instance, the paper by Botha (2008) that discusses the rather violent image of blood sacrifice in the New Testament.

12.See also Van Henten (2008:1587-1590) for a discussion of Girard. 
These are just some of the ways of treating the violent texts that Baumann describes, before she (2006:79-81) presents her own approach to these texts, which is inspired by some of these other approaches. I would like to describe her approach as a more honest approach in the sense that she does not shy away from engaging with the violence in these texts. Baumann (2006:81) sets out the following presuppositions. She does not want to relegate the depictions of divine violence to the status of 'marginal' images (Baumann 2006:81), but argues that they should be regarded as part of the centre or kernel of Old Testament theology. In this regard she disagrees with Brueggemann, who in his theology (1997) referred to the 'core testimony' and 'counter-testimony' (117-316; 317-406)..$^{13}$ Her reason for this is that violence is part of human existence and for theology to have any bearing on this given, violence should form part of our theological discussions. Furthermore, violent images of God help people to express their own experiences of violence and somehow provide people with tools to live with violence.

Baumann then sets out to read Old Testament texts in five steps. Firstly, she (2006:81) wants to read texts in their historical contexts. Questions asked in this first step include: what kind of violence did the authors of these texts experience or might they have experienced? Or, under what circumstances is violence attributed to God? Secondly, she (2006:81) attempts to contextualise these texts in the Ancient Near East; are there similar texts, motives, or traditions in Ancient Near Eastern writings which could help us to understand the biblical texts better? Thirdly, Baumann (2006:82) attempts to compare these texts with older texts in the Old Testament to see how traditions developed. In the context of which traditions are these violent images used? In the fourth place she asks about the texts' current literary context. What other images of God are used in this literary context which temper the violent images used? Finally, in the fifth place Baumann (2006:82-83) attempts to interpret these texts by asking how these texts helped the ancient authors to deal with their experiences of violence.

It might help if we see what Baumann does with certain texts. In the rest of her book she discusses five groups of texts. We will focus on the first ${ }^{14}$ group, namely texts where God is presented as a warlord, such as the references we find in Deuteronomy and Joshua and which all have to do with the conquest of the Promised Land (Baumann 2006:99). The texts under discussion are those in Deuteronomy and Joshua and describe the conquest of the Promised Land. We thus return to the question addressed to Regina Schwartz by her firstyear student: 'What about the Canaanites?' Baumann (2006:8485) starts by referring to the terrible Wirkingsgeschichte

13.Earlier in her book Baumann (2006:70-71) describes the theology of Brueggemann as a step in the right direction, because he takes the violent images of God seriously. She thus appreciates the fact that Brueggemann engaged with these texts, but she is critical of the way in which he did so.

14.The remaining four groups are: (2) Texts where God is portrayed as acting violently against mythical creatures, of which we find examples in the Psalms and other poetic texts (Baumann 2006:99-110); (3) Texts where God is portrayed as actin poetic texts (Baumann 2006:99-110); (3) Texts where God is portrayed as actin violently against metaphorical women. These are mostly found is prophetic texts (Baumann 2006.110-126); (4) God as violent judge of the world in texts such as Nahum and other examples from the psalms and the prophets (Baumann 2006:126-138); and (5) Images of God who acts violently towards an individual, where she uses the book of Job (Baumann 2006:138-154). [reception history] of these texts and refers to examples such as the Crusades, the Spanish conquering South America and, from South Africa's history, the Great Trek, where the Voortrekkers perceived themselves as Israelites conquering heathen Canaanites. She then names three representations in these texts which are today regarded as highly problematic, if not simply repulsive.

These are firstly the 'ban' texts such as Deuteronomy 7:1f and Deuteronomy 20:15-18, but also Joshua 10:28-43 and Joshua 11:10-22 (Baumann 2006:85-86). In the texts in Deuteronomy God orders the Israelites to practise the ban. In the texts from Joshua we are told how they did it. Baumann mentions that as far as methods of warfare could be reconstructed by historians, it seems that wars were not conducted as described in Joshua, but were far more carefully planned enterprises only undertaken when nations really felt threatened by others. With regard to historical context, Baumann adds that most biblical scholars would regard these narratives as historically highly unlikely. This is, of course, exactly what Schwartz said German scholars would do to make these texts less violent. Secondly, she refers to all the commands which order the Israelites to destroy the indigenous peoples of the land. These are often closely connected to the texts ordering the 'ban', although the term is not specifically used. Thirdly, Baumann (2006:86) discusses the role that YHWH plays in these texts and here it is the fact that YHWH commands the killing of the Canaanites; or worse, he kills them himself that is the issue addressed. In this regard texts such as Joshua 10 and Joshua 11 are important and especially Joshua 10:11, which the NRSV translates as follows:

${ }^{11}$ As they fled before Israel, while they were going down the slope of Beth-horon, the LORD threw down huge stones from heaven on them as far as Azekah, and they died; there were more who died because of the hailstones than the Israelites killed with the sword.

(NRSV translation of Jos 10:11)

Joshua 10 tells of how the Israelites conquered the five Amorite kings who came against them after they conquered Ai. The verse is not only about YHWH ordering the Amorites to be killed, but it portrays $\mathrm{YHWH}$ as a warlord who takes active part in the killing and whose killing surpasses that of the Israelites.

Baumann (2006:87-92) then discusses the 'religionsgeschichtliche Hintergrund' [religious historical background]; she lists many similar texts from the Ancient Near East. Many of these texts are from the Neo-Assyrian period and describe similar scenarios as that found in Joshua of other kings conspiring against the Assyrian king (see Jos 10:1-5), or other nations freely joining the Assyrians (see Jos 9), or of the Assyrian king's thorough conquest of these threatening nations (see Jos 10:16-26). ${ }^{15}$ She also refers to the Mesha stele, ${ }^{16}$ where

15.See also Römer (2007:86-90) for similar arguments about the meaning of Joshua 5-12 in the time of king Josiah in the Neo-Assyrian period. Römer (2007:89) is convinced that Neo-Assyrian texts were the 'literary model' behind the conquest narrative.

16.For an English translation of the Mesha stele see the following from Collins, which he obtained from ANET: 'And Chemosh said to me, "Go take Nebo from Israel!" So I went by night and fought against it from the break of dawn until noon, taking it and went by night and fought against it from the break of dawn until noon, taking it and
slaying all, seven thousand men, boys, women, girls and maid-servants, for I had devoted them to destruction for (the god) Ashtar-Chemosh' (Collins 2004b:192). 
the Moabite kings claim to have done deeds to Israelites that sound a lot like the 'ban' in the middle of the 9th century. Baumann also makes use of the work of Eckart Otto ${ }^{17}$ who has extensively compared Assyrian texts about warfare to biblical texts. But Baumann then reminds us that scholars usually regard these texts from Assyria and Moab as highly propagandistic and not necessarily as historically accurate. These texts and the reliefs found in Assyrian palaces which depict many of these deeds are mostly regarded as scare tactics used by the kings towards those from subordinate nations who visit the palace. Baumann (2006:91) then comes to one important conclusion. Although there are plenty of literary motifs shared by the Assyrian texts and the book of Joshua, there is one significant difference between these two. As far as historians know, Assyria had the military power to do these things when they wanted to, whilst Israel did not. Most scholars date the origins of these texts from the time of Josiah in the 7th century at the earliest. On these grounds, Baumann (2006:92) regards these texts from Joshua mostly as anti-Assyrian propaganda. These texts borrowed from Assyria, which was the major world force at that stage, were thus also critical of Assyria in the sense that the texts presented Judeans with an alternative worldview in which the Assyrians were not ruling the world, but $\mathrm{YHWH}$ was the ruler over all. ${ }^{18}$

Baumann's (2006:93-94) next step is to compare the narratives in Joshua with other texts in the Old Testament which could be regarded as presenting an alternative view. Here the book of Judges ${ }^{19}$ presents a different perspective on how Israel conquered the land; this is a version in which Israel struggles much more and does not have the same power as presented in the book of Joshua. In Judges many places are indicated to the reader as not being conquered by Israel, whereas Joshua had earlier declared that they were indeed conquered. That in itself supports the conclusion reached earlier that the stories of conquering the Canaanites in the book of Joshua were not historically accurate, but served other more theological and political purposes. For Baumann (2006), these stories told of a powerful past when Israel had no kings, but told in the time of later kings in Judah in the 7th century could have been understood as a theological critique of the king as such:

Nicht der König ist die entscheidende Machtinstanz, sondern JHWH. [The king is not the determining source of power, but rather YHWH.]

(Baumann 2006:93)

If the people had $\mathrm{YHWH}$ and he is so powerful then they do not need a king. These violent texts from Joshua thus have a double rhetorical function addressed towards the

17.See especially Otto (1999) for extensive comparisons between literature of the Ancient Near East and the Hebrew Bible on war and peace. For a more recent attempt see Crouch (2009), who engages with aspects such as cosmology and the ethics of war in the Ancient Near East. He grapples mostly with Neo-Assyrian texts, whereas Otto also discusses examples form Ugarit and Egypt.

18.Römer (2007:89) mentions that Joshua 10:12-13 would be a good example of an anti-Assyrian text where it is described that Joshua has control over the sun and moon who were Assyrian deities.

19.In the debate on the historical reliability of the conquest narrative many critical scholars would agree that Judges is probably more historically accurate than Joshua. See, for instance, the discussion by Collins (2005:41) on the two Israeli archaeologists, Dever and Finkelstein, who would both agree with Baumann. inside (against the Judean king) and the outside. ${ }^{20}$ Towards the outside they question the power of Assyria, and towards the inside they question the power of the Judahite king. The threat of Assyria as oppressor is negated by the power of $\mathrm{YHWH}$, but this is imposed by means of the same violent strategies of the Assyrians themselves. Baumann (2006:183) quotes the work of Rowlett (1996), who said:

As part of their imperial strategy, the Assyrians had undermined the sense of identity of the nations they conquered. Identity was being reasserted in the Joshua story, but it was done by adopting the violent ideology of the oppressors. The same ideology that had undermined their identity was now being used to exert their identity.

(Rowlett 1996:183)

Thus Assyrian propaganda tools were being used to undermine the Assyrian Empire. Next Baumann (2006:9498) discusses the greater literary context, which in this case would be what scholars call the Deuteronomistic history. A golden thread that runs through the whole Deuteronomistic history is an attempt to give meaning to the exile and the loss of the land by pointing out that Israel was unfaithful to YHWH. Usually it is argued that the writing process of Deuteronomistic history was not started before Israel fell to Assyria in $722 \mathrm{BCE}$. The conclusion of this writing process is usually regarded as occurring after the fall of Judah in 586 BCE. The Deuteronomistic history thus looks back at the time of the conquest as a kind of Heilszeit [time of salvation] in which the relationship between YHWH and Israel was untroubled and pure. Things changed, though, and the end result was the exile. Yet it was the same YHWH who gave the land originally and who eventually took it away:

Landgabe und Landverlust sind eng aneinander gekoppelt. [The gift of land and the loss of land are closely connected to each other.]

(Baumann 2006:95)

When Baumann (2006:98-99) finally attempts to interpret these texts theologically, she reminds her readers that these texts are narratives about what happened a long time before. These are not texts which ask their readers to act in the same manner themselves. The glorious past of Israel is portrayed with a strong dose of imagination and is generally regarded as fictive. Yet these texts create Israel's identity and they urge Israel to trust only in YHWH in extremely violent situations. The power to liberate lies with YHWH and not in Israel itself - or with the Assyrian kings for that matter. Still Baumann (2006:98) thinks that these texts are an embarrassment and warns that these texts as counter-propaganda still have the potential to incite people to violence and thus should be read carefully (2006:99).

Baumann (2006:98-99) seems rather unsure about whether these texts, when they were read in the time of Josiah, could still reflect something of the experienced violence; she rather sees more potential in their helping us to explore the violent potential in ourselves. Baumann would have answered

20.Baumann makes extensive use of the work of Rowlett (1996), but differs from her as well. For Baumann (2006:93) there is 'implizitier Königskritik' [implicit criticism of the king] present in the presentation of pre-monarchic Israel conquering powerful nations with only the help of YHWH. Rowlett (1996:183) understands this powerful nations with only the help of YHWH. Rowlett (1996:183) understands this
rhetoric as supporting the Judean king and acts as a kind of warning for those who rhetoric as supporting the Judean king and
wanted to resist the central government. 
Schwartz's first-year student that what happened to the Canaanites never actually happened and that they were simply characters in a story which much later helped Judah to create its own identity in the light of the Assyrian hegemony. Baumann would still agree with Schwartz that these texts have oppressive potential and that they have indeed already done much harm.

\section{Conclusion}

When one formulates the problem of what role Bible critics could play in reading violent biblical texts, one has to start off with a rather naïve proposition: what Bible critics do with the Bible matters to ordinary people. I am not sure that it really does. I am not sure that ordinary believers really take their cue from Bible critics. We must acknowledge that there is a vast difference between the way that lay Christians read the Bible, and what Bible critics and other theologians do with it. Taking this gap seriously is still one of our biggest challenges.

The difference between Schwartz and Baumann could be summed up as follows: in a sense Baumann does what Schwartz says we should not do. She reads the conquest narrative in its historical context as constructed by biblical critics. This reading changes the conquest narrative to a fictive story about identity. Baumann accounts for her reading as an attempt to understand. Schwartz (1997:61) had said that this is an irresponsible thing to do presumably because, even if it makes the biblical texts more palatable, it does not change their 'cultural effect'. What Schwartz calls 'cultural effect' is called Wirkungsgeschichte [reception history] by others. Yet Baumann is also concerned with the Wirkungsgeschichte [reception history] of a text and consistently acknowledges that, although her reading helps us to understand these violent texts better, it still does not change the potential of these texts to incite people to violence. One could also add that Wirkungsgeschichte [reception history] is probably something that has more to do with ordinary readers than Bible critics.

The suggestion by Regina Schwartz that we rewrite the Bible is simply so far removed from the life of everyday believers that very few people in churches today would probably take that suggestion seriously (not in South Africa, in any case). Most would feel extremely threatened by it. Yet I do think that, as scholars, we should take her arguments seriously. Her analysis of the way in which the Old Testament constructs identity and the violence which follows is clear and thoughtprovoking. We cannot simply sweep her observations under the carpet.

Yet the main ingredient that is lacking in her work, which is very much part of Baumann's approach, is the fact that Schwartz does not attempt to understand. And this is where Baumann seems to me to be making the more constructive contribution. Before we judge the ancient authors of the Bible as hopelessly violent barbarians, we as scholars should at least attempt to understand who they were, and how they lived, and why they used such violent images to say things about God. Baumann does exactly that by using many of the exegetical tools available to Bible critics. She helps us to understand these images better in order to judge them less. Schwartz's reading sounds very condescending and this is fine if you are reading the Bible in a fairly crimefree society such as hers. In a violent society such as South Africa, Baumann's reading rings truer, simply because it acknowledges the violent reality of ancient Israel; this is a reality that South Africans can identify with. One could also ask whether South Africans would be able to identify with the new violence-free Bible that Schwartz intends to write.

Baumann is not shying away from the embarrassment of these violent images, nor is she attempting to pretty them up in any way. She has the honesty to argue that the violent images should be part and parcel of our theology and should not be ignored in any way or side-lined as the not-so-centralparts of the Hebrew Bible's representation of YHWH.

Baumann's reading also has greater potential value in the sense that violent stories like these might help ordinary people to express something of their own experienced violence. This kind of reading presumes that talking about violence might keep people from committing it. This view has potential, but I am not totally convinced. Baumann clearly states that the kind of counter-propaganda that we find in the book of Joshua also has the potential to incite violence. It all boils down to how we read these texts. This brings us back to the gap between Bible critics and ordinary readers of the Bible.

John Collins (2004a:32-33) ends his book with a point about Oliver Wendell Holmes, the great American jurist, who said:

\begin{abstract}
... that he had entered the Civil War brimming with certitude over the righteousness of abolition, which surely was a righteous cause. By the end of the war he had drawn a different lesson, that certitude leads to violence.
\end{abstract}

(Collins 2004a:32-33)

Collins (2004:33) then concludes that the contribution of biblical critics could lie in our ability to show that the certitude with which many people speak of the Bible is an illusion.

This is probably not something which will be received with too much enthusiasm by most churches. Churches and religions are built on certitude. In that sense Assmann has a point with his 'Mosaic distinction', which is another kind of certitude which can indeed lead to violence. What role could Bible critics really play in helping people to read the Bible more responsibly? Those of us in teaching positions, where we teach the pastors and ministers of the future, probably have the best opportunity to teach our students to read more responsibly. By 'responsible' I mean the kinds of readings (such as Baumann's) which take ancient contexts seriously, but which also ask about the effect of violent texts on contemporary society (such as those of both Schwartz and Baumann). If future ministers and pastors read biblical texts more responsibly, ordinary readers will hopefully follow suit. 
There is another question which we need to address better in violent South Africa and that is the relation between violence and identity. Schwartz, Assmann and Baumann have all engaged with this issue in their own fashion, but the need for South Africa is to construct an identity which does not need violence to survive. In the search for an answer to this issue, Bible critics have a role to play, since we engage with ancient texts where violence and identity politics go hand in hand.

\section{References}

Albertz, R., 2009, 'Monotheism and violence: How to handle a dangerous biblical tradition', in J. van Ruiten \& J.C. de Vos (eds.), The land of Israel in Bible, history, and theology studies in honour of Ed Noort, pp. 373-388, Brill, Leiden.

Assmann, J., 2010, The price of monotheism, Stanford University Press, Stanford, CA.

Assmann, J., 2000, Herrschaft und heil: politische Theologie in Altägypten, Israel und Europa [Power and salvation: Politcal theology in Old Egypt, Israel and Europe]. C. Hanser, Munich.

Assmann, J., 1997, Moses the Egyptian: The memory of Egypt in western monotheism, Harvard University Press, Cambridge, MA.

Baumann, G., 2006, Gottesbilder der Gewalt im Alten Testament verstehen [Understanding divine images of violence in the Old Testament]. WBG, Darmstadt.

Botha, P.J.J., 2008, 'Bloedoffers en morele vorming: Gewelddadigheid as faset van Christelike tradisies' [Blood sacrifices and moral formation: Violence as a facet of Christian traditions], Hervormde Teologiese Studies 64(4), 1601-1631.
Brueggemann, W., 2009, Divine presence amid violence. Contextualizing the Book of Joshua, Cascade Books, Eugene, OR.

Brueggemann, W., 1997, Theology of the Old Testament. Testimony, Dispute, Advocacy, Fortress Press, Minneapolis, MN.

Collins, J.J., 2005, The Bible after Babel. Historical criticism in a Postmodern Age, Eerdmans, Grand Rapids, MI.

Collins, J.J., 2004a, Does the Bible justify violence?, Fortress Press, Minneapolis, MN.

Collins, J.J., 2004b, Introduction to the Hebrew Bible, Fortress Press, Minneapolis, MN.

Crouch, C.L., 2009, War and ethics in the Ancient Near East. Military violence in light of cosmology and history, Walter de Gruyter, Berlin. doi:10.1515/9783110223521

Noort, E., 1998, Das Buch Josua. Forschungsgeschichte und Problemfelder [The Book of Joshua. Research history and problem areas]. Wissenschaftliche Buchgesellsschaft, Darmstadt.

Otto, E., 1999, Krieg und Frieden in der Hebräishen Bibel und im Alten Orient. Aspekte für eine Friedensordnung in der Moderne [War and peace in the Hebrew Bible and in the Ancient Near East. Aspects of an order of peace in the modern world]. Kohlhammer, Stuttgart.

Römer, T., 2007, The so-called Deuteronomistic history. A sociological, historical and literary introduction, T \& T Clark, London.

Rowlett, L.L., 1996, Joshua and the rhetoric of violence. A new historicist analysis, Sheffield Academic Press, Sheffield.

Schwartz, R.M., 1997, The curse of Cain. The violent legacy of monotheism, University of Chicago Press, Chicago, IL.

Snyman, G., 2010, 'Review of: Divine presence amid violence: Contextualizing the Book of Joshua by Walter Brueggemann', in Review of Biblical Literature 04/2010, viewed 03 December 2010, from http://www.bookreviews.org/pdf/7156_7777. pdf

Van Henten, J.W., 2008, 'Religie, Bijbel en Geweld' [Religion, Bible and Violence], Hervormde Teologiese Studies 64(4), 1583-1600 